\title{
BIOSYNTHESIS PRODUCTS OF PSEUDOMONAS SP. PS-17 STRAIN METABOLITES. 1. OBTAINING AND THERMAL CHARACTERISTICS
}

\author{
Ihor Semeniuk ${ }^{1}$, Viktoria Kochubei ${ }^{2}$, Volodymyr Skorokhoda ${ }^{2,}$, \\ Tetyana Pokynbroda', Halyna Midyana ${ }^{1}$, Elena Karpenko', Viktor Melnyk ${ }^{2}$
}

https://doi.org/10.23939/chcht14.01.026

\begin{abstract}
Biogenic surfactants (rhamnolipid biocomplex, dirhamnolipid and exopolysaccharide) and polyhydroxyalkanoate biopolymer which are the new biosynthesis products of Pseudomonas sp. PS-17 strain have been obtained. The thermal transformation of these products has been studied in the air in the temperature range of 293-1273 K. Thermolysis and IR spectroscopy revealed a formation of rhamnolipid biocomplex between rhamnolipids and exopolysaccharide upon acidification of the culture fluid supernatant to $\mathrm{pH}=3$. Cellular polymer polyhydroxyalkanoate - was identified by UV-Vis spectroscopy. According to the thermal analysis, the melting point and initial degradation temperature of polyhydroxyalkanoate were determined. Using the Vicat method, the heat resistance of the polymer was determined.
\end{abstract}

Keywords: Pseudomonas sp. PS-17, biosurfactant, ramnolipids, polysaccharides, polyhydroxyalkanoate, biopolymer, thermal analysis, UV-Vis spectroscopy, IR spectroscopy.

\section{Introduction}

One of the most promising areas of modern bioengineering and polymer synthesis technology is the production of new substances and polymers capable of biodegradation and suitable for use in various fields of human activity, in particular, in biomedicine, pharmacy, and the packaging industry. When developing the advanced technologies, the particular attention is paid to their environmental safety. The problem of synthetic surfactants usage remains very urgent due to their significant toxicity and low degradation capacity. So,

\footnotetext{
${ }^{1}$ Department of Physical Chemistry of Fossil Fuels,

L.M. Lytvynenko Institute of Physical Organic Chemistry and Coal Chemistry of the NAS of Ukraine

3a, Naukova St., 79060 Lviv, Ukraine

${ }_{2}^{2}$ Lviv Polytechnic National University,

12, Bandery St., 79013 Lviv, Ukraine

vskorohoda@yahoo.com

(c) Semeniuk I., Kochubei V., Skorokhoda V., Pokynbroda T., Midyana H., Karpenko E., Melnyk V., 2020
}

biogenic surfactants (BS), in particular those of microbial origin, cause a great interest. Detailed studies of BS in recent years have shown the possibility of their widespread use in various industries and agriculture $[1,2]$. This is due to their ability to significantly reduce a surface and interfacial tension in solutions, to emulsify various substrates, to regulate the wettability of surfaces, etc. [3]. Some microbial surfactants are considered to be more effective than synthetic ones, because their biodegradability and low toxicity make them particularly promising when creating new compositions for environmentally friendly technologies [4].

The main impetus for the development of microbial biopolymers is the problem of recycling plastic waste, the volume of which is increasing every year. New regulations on environmental protection and increasing worldwide public demands on the environment stimulate the search for new biocompatible materials, as well as the creation of environmentally friendly technological processes [5]. The difference of biopolymers (biodegradable polymers) from other plastics is that they decompose in the environment under the action of abiogenic and biogenic factors. Polyhydroxyalkanoates (PHA) are biopolymers obtained from cheap natural raw materials via biosynthesis using various strains of microorganisms. PHA are characterized by a complex of valuable properties; in particular they are thermostable, resistant to corrosive chemicals and UV radiation, compatible with different monomers and capable of extruding into different shapes, films, filaments; their strength is comparable to polypropylene, they are nontoxic, non-allergenic and biodegradable [6]. That is why they can be used in various industries: the production of biodegradable packaging materials and molded goods, non-woven materials, disposable napkins, personal care products, films and fibers, water-repellent coatings for papers and cardboard, etc. Another advantage of natural polymers is the use of renewable raw materials for their production [7]. This creates the prospect of developing and using PHA to replace approximately $50 \%$ of polymeric materials synthesized from natural gas and oil. 


\section{Experimental}

\subsection{Materials}

We used for research four technologically important biomaterials - products of Pseudomonas sp. PS-17 biosynthesis (from the collection of the Department of Physical Chemistry of Fossil Fuels, L.M. Lytvynenko Institute of Physical Organic Chemistry and Coal
Chemistry of the NAS of Ukraine): extracellular surfaceactive rhamnolipid biocomplex (RBC) containing surfaceactive rhamnolipids and exopolysaccharides, rhamnolipids (RL), exopolysaccharide (EPS), and cellular mediumchain polyhydroxyalkanoat (mcl-PHA) containing 3hydroxyhexanoate $(3 \mathrm{HHx}), 3$-hydroxioctaonate $(3 \mathrm{HO}), 3-$ hydroxydecanoate (3HD) and 3-hydroxydodecanoate (3HDD). All of them are biopolymers with 100-30,000 degree of polymerization (Fig. 1) $[8,9]$.

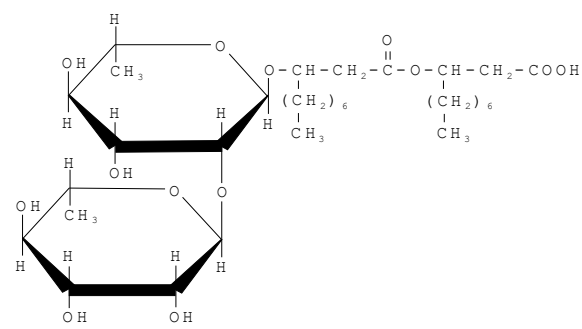

a)

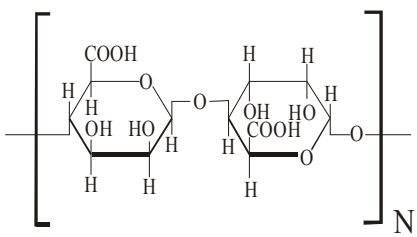

b)

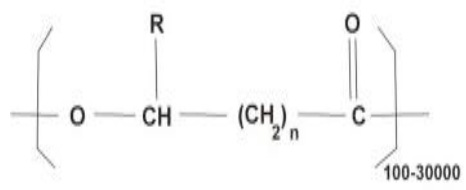

c)

Fig. 1. Structural formulae of dirhamnolipid RL-2 (a); exopolysaccharide EPS (b) and polyhydroxyalkonoate PHA (c)

The microorganisms were cultivated on an optimized nutrient medium with glycerol as a carbon source in Erlenmeyer flasks $(750 \mathrm{ml})$ with a working volume of $150 \mathrm{ml}$ on a rotary shaker $(220 \mathrm{rpm})$ at $303 \mathrm{~K}$ for 5 days. Pseudomonas sp. PS-17 was grown on a liquid nutrient medium $(\mathrm{g} / \mathrm{l})$ : glycerin $30.0 ; \mathrm{NaNO}_{3}$ 4.0; $\mathrm{K}_{2} \mathrm{HPO}_{4} \cdot 3 \mathrm{H}_{2} \mathrm{O} \quad 2.0 ; \mathrm{KH}_{2} \mathrm{PO}_{4} \quad 1.2 ; \mathrm{MgSO}_{4} \cdot 7 \mathrm{H}_{2} \mathrm{O} \quad 0.5$; sodium citrate $5.0(\mathrm{pH}=7.0)$ [10]. From the culture broth (CB) the cells were extracted by centrifugation at $6,000 \mathrm{rpm}$ for $15 \mathrm{~min}$. RBC containing surface-active rhamnolipids, which are esters of rhamnose and 3oxydecanoic acid, as well as polysaccharide of alginate nature were precipitated from the $\mathrm{CB}$ supernatant by acidification to $\mathrm{pH}=3$ [11]. Dirhamnolipids were extracted from $\mathrm{RBC}$ with a Volch solution followed by evaporation under vacuum [12]. The exopolysaccharide was prepared via isopropanol precipitation (1:2) from the CB supernatant.

The surface and interfacial tensions of rhamnolipid surfactants were measured with a platinum ring (Du-Nui method) [13] on a Krüss K6 tensiometer (Krüss $\mathrm{GmbH}$, Germany). The critical concentration of micelle formation (CCM) was determined using isotherms of surface tension of surfactant solutions. The emulsifying activity of $E_{24}$ relative to hydrophobic substances was defined as the ratio of the emulsion layer height to the height of the mixture layer (\%) after $24 \mathrm{~h}$ [14].

Biopolymer-polyhydroxyalkanoate was extracted from the cells obtained after centrifugation of the postfermentation $\mathrm{CB}$. The cells were rinsed twice with $\mathrm{NaCl}$ solution $(0.9 \mathrm{wt} \%)$ and centrifuged for $15 \mathrm{~min}$. The precipitate was collected, dried at $333 \mathrm{~K}$ till the constant weight and cooled to room temperature. To remove PHA from biomass, dry cells were disintegrated using isopropanol and ultrasound $(1 \mathrm{~h}, 303 \mathrm{~K})$. After centrifugation $(15 \mathrm{~min}, 6,000 \mathrm{rpm})$, the precipitate was extracted during 5 cycles in a Soxhlet apparatus using chloroform. The solvent was evaporated under vacuum till a solid residue was obtained. To purify the polymer, it was dissolved in chloroform and precipitated with cold isopropanol. The precipitate obtained was filtered (decanted), dried and then analyzed.

\subsection{Methods}

Thermal analysis was performed on a Q-1500D derivatograph of the Paulik-Paulik-Erdey system connected to a computer in the temperature range of 293 $1273 \mathrm{~K}$ with a free air access to the oven. The heating rate was $5 \mathrm{~K} / \mathrm{min}$. The averaged weight of the samples was $80 \mathrm{mg}$, the reference substance was alumina [15].

Heat resistance was determined according to the Vicat method. The tablets with a diameter of $10-11 \mathrm{~mm}$ and a thickness of 3-5 $\mathrm{mm}$ were formed for the analysis. The tests were carried out using Hepler consistometer with a load of $50 \mathrm{~N}$. The temperature at which the device tip is pressed into the sample by $1 \mathrm{~mm}$ is an indicator of the heat resistance.

The infrared absorption spectra of RBC and RL-2 samples, pre-dried to a constant mass and obtained in potassium bromide discs, were recorded in the range of $4000-500 \mathrm{~cm}^{-1}$ on a Termo-Nicolet-380 infrared spectrophotometer (USA). 
UV-Vis absorption spectra of PHA solutions in chloroform (within 200-800 nm) were analyzed in $1 \mathrm{~mm}$ cells using a UV mini-1240 spectrophotometer ("Shimadzu", Japan).

\section{Results and Discussion}

Surfactant biogenic products - extracellular dirhamnolipid (RL-2), exopolysaccharide (EPS), rhamnolipid biocomplex (RBC), and cell polymer-polyhydroxyalkanoate (mcl-PHA) were obtained via cultivation of Pseudomonas sp. PS-17 on the optimized nutrient media [16].

To characterize these substances, their physical and chemical properties were investigated. It has been established that RBC containing rhamnolipids and polysaccharide-alginate with the ratio of 4:1 [17] has the high emulsifying and surface activity. Table 1 represents the physico-chemical properties of the obtained RL and RBC.

Since PHA is decomposed into 3-hydroxy acids found in animal tissues, it is biodegradable and biocompatible [18].

When using thermal analysis it is possible to investigate a thermal stability of the compound and get a clear idea of the nature of the processes that take place during heating [19]. The results of thermal analysis are presented in the form of thermograms (Figs. 2-5).

Thermolysis of RL-2 proceeds in five stages (Fig. 2 ). At the first stage, in the temperature range of 293$466 \mathrm{~K}$, the residual solvent is separated and the sample is softened. This process is accompanied by a slight mass loss $(\Delta m=2.70 \%)$ on the TG curve and the appearance of endothermic effect on the DTA curve. At the second stage of thermolysis, in the temperature range of 466-509 K, there is a thermal destruction of aliphatic fragments of the sample with the formation of volatile degradation products. This process is accompanied by the appearance of a clear extremum on the DTG curve, and endothermic effect on the DTA curve. At the third stage of thermolysis, in the temperature range of $509-572 \mathrm{~K}$, there is a deeper destruction of the aliphatic fragments, resulted in the combustion of the destruction residues. This process is accompanied by a rapid mass loss $(\Delta m=54.60 \%)$ and a deep extremum on the DTG curve with the maximum at $532 \mathrm{~K}$. Endothermic effect appeared on the DTA curve within this temperature range, is completed by the deviation of the DTA curve into the region of exothermic effects. The total mass loss at the second and third stages of thermolysis is $75.53 \%$, which is in a good agreement with the theoretical calculations of the loss of the aliphatic part of the molecule RL-2 taking into account hydroxyl and methyl groups of rhamnose cycles $(\Delta m=75.1 \%)$.

At the fourth stage of thermolysis, in the range of $572-680 \mathrm{~K}$, a thermooxidative destruction of the fragments of RL-2 molecule cyclic part occurs. In this temperature range, an exothermic effect is observed on the DTA curve. At the fifth stage, in the temperature range of $680-845 \mathrm{~K}$, a deeper destruction of the RL-2 rhamnose cycles is completed with the combustion of the destruction residues. This process is accompanied by the appearance of clear exoeffect on the DTA curve, with the maximum at $801 \mathrm{~K}$.

Physico-chemical properties of RL and RBC

\begin{tabular}{|c|c|c|c|c|}
\hline Sample & Surface tension, $\mathrm{mN} / \mathrm{m}$ & Interfacial tension $(n$-heptane $), \mathrm{mN} / \mathrm{m}$ & $\mathrm{CCM}, \mathrm{mg} / \mathrm{l}$ & Emulsifying index $\mathrm{E}_{24}, \%$ \\
\hline RL & $28.8 \pm 0.3$ & $0.12 \pm 0.01$ & $20-70$ & $50-60$ \\
\hline RBC & $29.2 \pm 0.3$ & $0.17 \pm 0.01$ & 120 & 85 \\
\hline
\end{tabular}

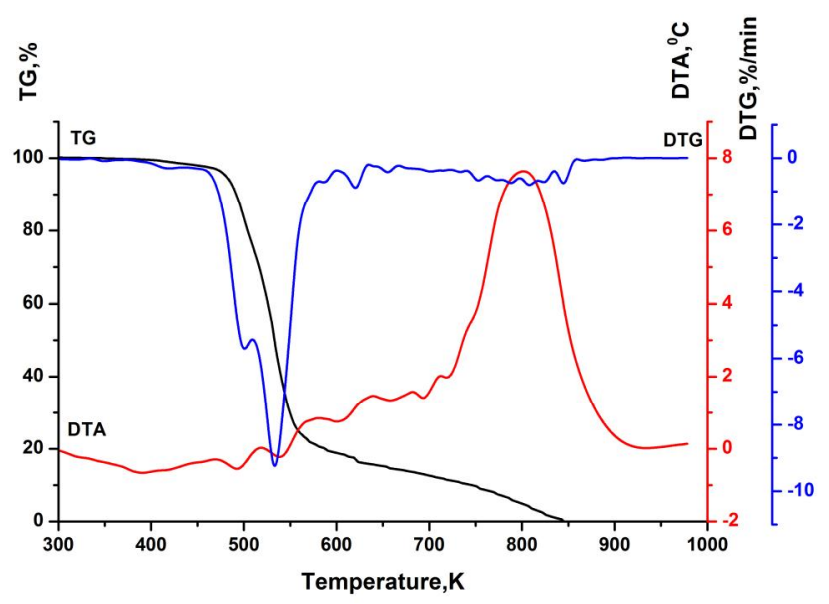

Fig. 2. Thermogram of the RL-2 sample 
Thermolysis of the RBC also takes place in five stages (Fig. 3). The appearance of the TG, DTA, and DTG curves is similar, indicating a similar mechanism of thermolysis and chemical composition of the samples.

The slight mass loss at the first stage of thermolysis, which takes place in the temperature range of $293-457 \mathrm{~K}$, corresponds to the evolving of volatile components present in the sample. Within this temperature range an endothermic effect appears on the DTA curve. At the second and third stages of thermolysis, which take place in the temperature ranges of $457-512 \mathrm{~K}$ and $512-558 \mathrm{~K}$, respectively, the thermal destruction of the aliphatic part is completed by the combustion of the destruction residues. These processes are accompanied by intense mass losses $(\Delta m=20.57 \%$ for the second stage and $\Delta m=51.41 \%$ the third stage) and the appearance of endothermic effects on the DTA curve. The third stage of thermolysis is completed with the deviation of the DTA curve toward the area of exothermic effects.

The total value of mass loss of the $\mathrm{RBC}$ at the second and third stages of thermolysis $(\Delta m=71.98 \%)$ is very close to the value of RL-2 $(\Delta m=75.53 \%)$. This indicates the close chemical composition of the samples. The less mass loss of the RBC indicates the less content of aliphatic fragments capable of destruction and oxidation at low temperatures.

At the fourth and fifth stages of RBC thermolysis, taking place within $558-630 \mathrm{~K}$ and $630-965 \mathrm{~K}$, respectively, the destruction of the sample cyclic fragments and the combustion of the destruction residues are observed. These processes are accompanied by the appearance of exothermic effects on the DTA curve.

It should be noted that, unlike RL-2, the sample of $\mathrm{RBC}$ is characterized by the presence of residual mass at the temperatures above $973 \mathrm{~K}$. This indicates the presence of thermally stable components in it.

Thermolysis of EPS proceeds in four stages (Fig. 4). At the first stage, in the range of $293-453 \mathrm{~K}$, the bound water is separated from the sample. This process is accompanied by a significant mass loss of the sample $(\Delta m=27.21 \%)$ and the appearance of deep endothermic effect on the DTA curve.

Within the temperature range of $453-665 \mathrm{~K}$ (the second stage), the EPS thermal oxidative destruction takes place, which is followed by a gradual loss of the sample mass $(\Delta m=16.26 \%)$ and the appearance of a clear exothermic effect on the DTA curve.

In the temperature range of $665-773 \mathrm{~K}$ (the third stage), there is a gradual combustion of the destruction residues and formation of the carbonized residue which begins to burn at the temperatures above $773 \mathrm{~K}$ at the fourth stage of thermolysis. The processes of combustion of the destruction residues and the carbonized residue of the EPS sample are accompanied by the appearance of clear exoeffects on the DTA curve.

It should be noted that combustion of the pyrolytic residue continues at temperatures above $973 \mathrm{~K}$. The residual weight of the sample after the fifth stage of thermolysis is $43.06 \%$. The presence of residual mass $(2.17 \%)$ in the RBC sample at the temperatures above 973 K (Fig. 3) confirms the presence of a certain amount of bound EPS in it.

The thermal analysis results of RL-2 and RBC are in good agreement with IR spectroscopy data.

The shift of $-\mathrm{OH}$ groups vibrations $\left(3325.59 \mathrm{~cm}^{-1}\right)$ in the RBC spectrum compared to that of RL-2 $\left(3345.81 \mathrm{~cm}^{-1}\right)$ may indicate the formation of non-covalent RL-2 complexes with EPS. The presence of bound polysaccharide in the RBC is also confirmed by the decrease in the intensity of the characteristic absorption bands of the following groups and bonds: 1739 and $1731 \mathrm{~cm}^{-1}$ (stretching vibrations of $-\mathrm{C}=\mathrm{O}$ groups); $1165-1052 \mathrm{~cm}^{-1}$ (stretching vibrations of $-\mathrm{C}-\mathrm{O}-\mathrm{C}-$ bonds) $[20,21]$.

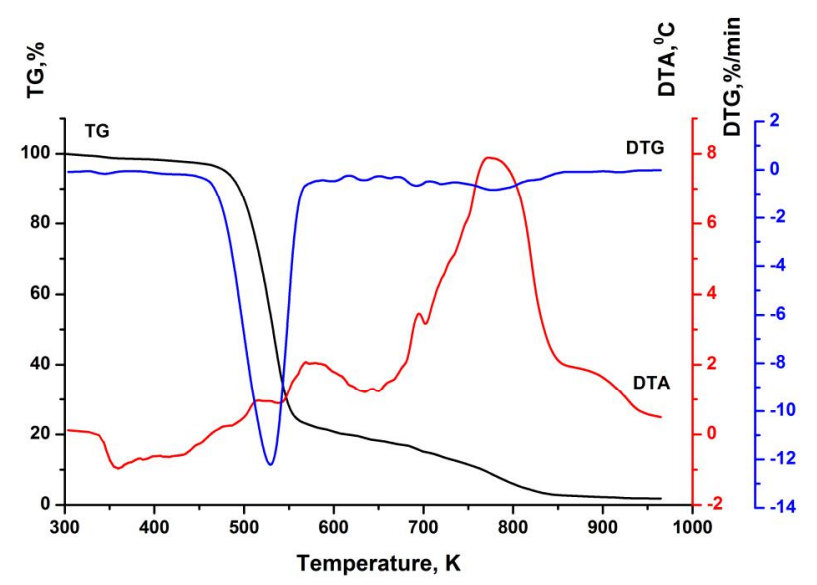

Fig. 3. Thermogram of RBC

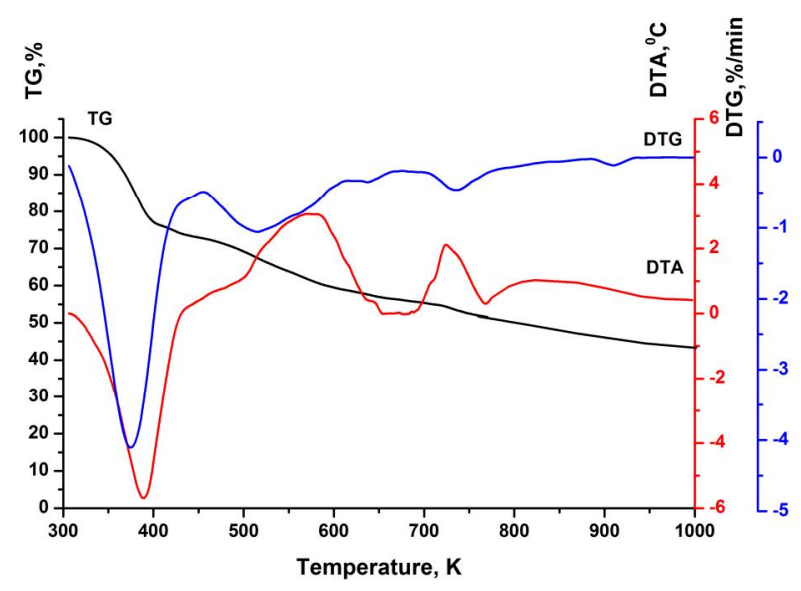

Fig. 4. Thermogram of EPS 
Complex physicochemical study of cellular biopolymer of Pseudomonas sp. PS-17 strain (medium chain polyhydroxyalkanoate, mcl-PHA) was performed using UV-Vis spectroscopy, the Vickat method and thermal analysis.

Fig. 5 shows thermograms of PHA within a wide temperature range of 293-1273 K. Fig. 6 contains the data of complex thermal analysis in the region of low temperatures $293-423 \mathrm{~K}$.

At the first stage of thermolysis, in the temperature range of 293-326 K, the sample melts (Fig. 6). This process takes place without mass loss and is accompanied by a clear endothermic effect on the DTA curve, with the maximum at $319 \mathrm{~K}$.

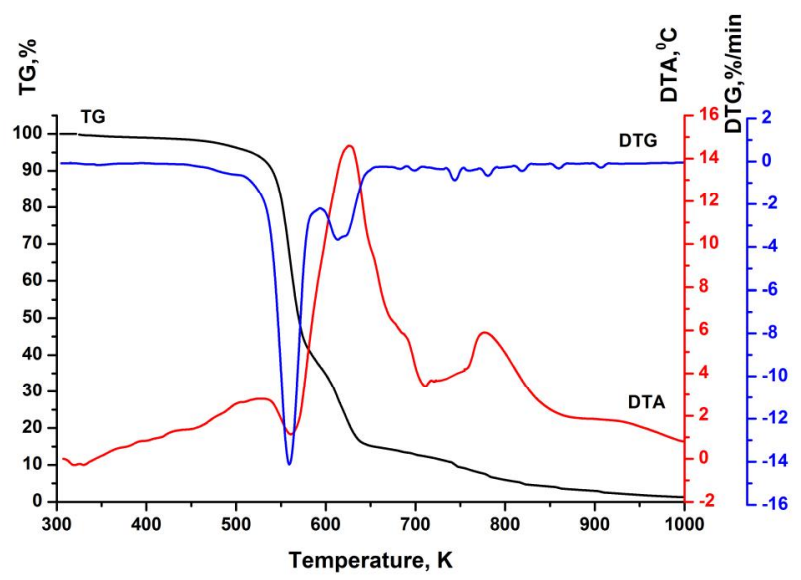

Fig. 5. Thermogram of PHA

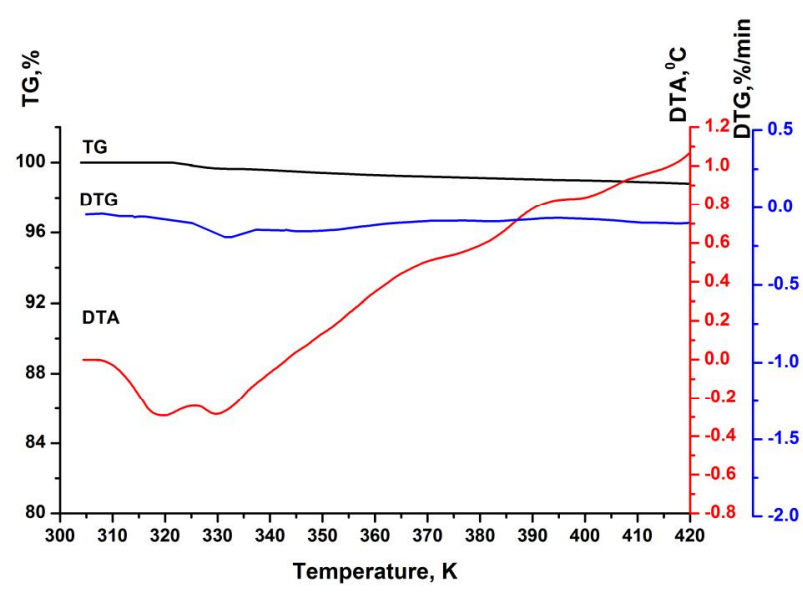

Fig. 6. Thermogram of PHA in the range of low temperatures

The data of differential thermal analysis of PHA in the low-temperature region within the limits of the experiment error are in agreement with the results obtained by the Vickat method ( $321 \mathrm{~K})$.

In the temperature range of 326-499 K (Fig. 5), at the second stage of thermolysis, the volatile substances presented in the PHA sample are evolved. In the same temperature range, the thermo-oxidation processes begin in the biopolymer. The small mass loss $(3.7 \%)$ and deviation of the DTA curve toward the area of exothermic effects confirm this fact.

The rapid PHA mass loss is observed at the temperatures above $499 \mathrm{~K}$. In the temperature range of 499-594 K, at the third stage of thermolysis, there is a deep thermo-oxidative destruction of the biopolymer. Significant mass loss of the sample $(59.42 \%)$ corresponds to this process. An exothermic effect appears on the DTA curve, with the maximum at $529 \mathrm{~K}$, which further transforms into a clear endothermic effect (the maximum at $561 \mathrm{~K}$ ). The appearance of endoeffect indicates the occurrence of deep destructive processes in the biopolymer under the influence of high temperatures.

In the temperature range of $594-711 \mathrm{~K}$, at the fourth stage of thermolysis, the destruction residues of the sample are burned. This process is accompanied by the mass loss of $24.51 \%$ and the appearance of a clear exothermic effect on the DTA curve. Thermolysis of PHA is completed by combustion of the pyrolytic residue within $711-1023 \mathrm{~K}$, at the fifth stage of thermolysis.

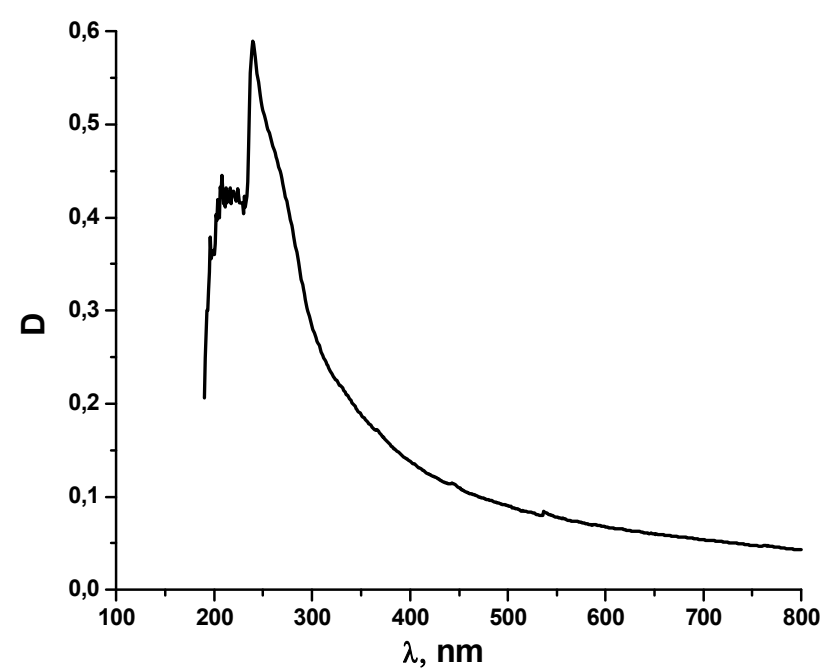

Fig. 7. UV-Vis spectrum of the biopolymer

According to UV-Vis investigations of the biopolymer $(0.1 \%$ solution in chloroform), the absorption maximum at $239 \mathrm{~nm}$ (Fig. 7) is observed. The value obtained is within the range of 230-240 nm, typical of polyhydroxyalkanoates [22] and indicates their formation.

\section{Conclusions}

Microbial synthesis was performed and the physico-chemical properties of the surfactants of 
Pseudomonas sp. PS-17 strain were investigated. The synthesized compounds are recommended to be used to produce environmentally friendly products instead of synthetic surfactants and polymeric materials.

IR-spectroscopic and thermal analysis confirmed the formation of a rhamnolipid biocomplex between dirhamnolipid and polysaccharide of Pseudomonas sp. PS-17.

It is shown that the melting point of the synthesized polyhydroxyalkanoate, calculated according to thermal analysis, quantitatively coincides with the values of the heat resistance obtained by the Vicat method.

According to thermolysis, deep thermo-oxidative and destructive processes in the PHA sample are observed only at the temperatures above $499 \mathrm{~K}$, which indicates a sufficiently high thermal stability of the obtained biopolymer.

The high values of melting point and heat resistance allow to propose PHA to be used for the production of household products (packaging materials), in the food industry (for beverages and products), in agriculture (for the coating of seeds, fertilizers and pesticides). The ecological safety of PHA decomposition products allows to use them to prolong the action of drugs, to obtain durable biodegradable surgical material, to manufacture elements of the musculoskeletal system implants.

\section{References}

[1] Mulligan C., Sharma S., Mudhoo A.: Biosurfactants. Research Trends \& Applications. CRC Press, Taylor\&Francis Group, Boca Raton 2014.

[2] Chong H., Li Q.: Microbial Cell Factories, 2017, 16, 137. https://doi.org/10.1186/s 12934-017-0753-2

[3] Irorere V., Tripathi L., Marchant R. et al.: Appl. Microbiol. Biotechnol., 2017, 101, 3941. https://doi.org/10.1007/s00253-0178262-0

[4] Karpenko O., Voloshynets V., Karpenko I. et al.: Naukovi Visti Kyiv. Polytech. Inst., 2017, 6, 7.

[5] Canet R., Birnstingl J., Malcolm D. et al.: Biores. Technol., 2002, 76, 113. https://doi.org/10.1016/S0960-8524(00)00093-6

[6] Bugnicourt E., Cinelli P., Lazzeri A., Alvarez V.: Express

Polym. Lett., 2014, 8, 791.

https://doi.org/10.3144/expresspolymlett.2014.82

[7] Kit Y., Pau L.: Economic and environmental analysis of PHAs production process

Clean. Technol. Environ. Policy, 2017, 19, 1941.

https://doi.org/10.1007/s 10098-017-1377-2

[8] Raza Z., Abid S., Banat I.: Int. Biodeter. Biodegrad., 2018, 126, 45. https://doi.org/10.1016/j.ibiod.2017.10.001

[9] Kim D., Kim H., Chung M., Rhee Y.: J. Microbiol., 2007, 45, 87. [10] Karpenko E., Pokinbroda T., Makitra R., Palchikova E.: Rus. J. Gen. Chem., 2009, 79, 2637.

https://doi.org/10.1016/j.ibiod.2017.10.001
[11] Karpenko E., Shulga A., Vildanova-Marzishin R. et al.: Mikrobiol. Zh., 1996, 52, 78.

[12] Folch J., Lees M., Sloane Stanley G.: J. Biol. Chem., 1957, 226, 497.

[13] Abramzon A., Zaichenko L., Fainhold S.:PoverhnostnoActivnye Veshestva. Sintez, Analiz, Svoistva, Primenenie. Khimia, Leningrad 1988.

[14] Belsky I., Gutnick D., Rosenberg E.: FEBS Lett., 1979, 101,

175. https://doi.org/10.1016/0014-5793(79)81320-4

[15] Semeniuk I., Kocubei V., Karpenko O. et al.: Vopr. Khim. Khim. Tekhnol., 2019, 4, 150. https://doi.org/10.32434/0321-40952019-125-4-150-156

[16] Yerokhin V., Pokynbroda T., Karpenko O., Novikov V.:

Visnyk Nats. Univ. Lviv. Politehnika, 2006, 553, 124.

[17] Karpenko E., Martynyuk N., Vildanova R., Shulga A.: Ukr. Pat. 71792. Publ. Dec. 15, 2004.

[18] Williams S, Martin D.: Applications of Polyhydroxyalkanoates (PHA) in Medicine and Pharmacy. Biopolymers Online. Wiley Publishers, Marchessault, Canada 2005.

https://doi.org/10.1002/3527600035.bpol4004

[19] Khovanets' G., Makido O., Kochubei V. et al.: Chem. Chem. Technol., 2017, 11, 158. https://doi.org/10.23939/chcht11.02.158

[20] Tarasevych B.: IK-Spektry Osnovnykh Klassov

Organicheskykh Soedineniy. MGU im. Lmonosova, Moskva 2012.

[21] Pashynska V., Glamazda A., Plokhotnichenko A. et al.: XXIX

Eur. Congress on Molecular Spectroscopy EUCMOS 2008. Croatia, Opatija 2008, 171.

[22] Sato S., Andreeßen B., Steinbüchel A.: AMB Express, 2015, 5, 1. https://doi.org/10.1186/s13568-015-0105-8

Received: September 04, 2018 / Revised: November 17, 2018 / Accepted: February 11, 2019

\section{ПРОДУКТИ БІОСИНТЕЗУ МЕТАБОЛІТІВ ШШTAMУ PSEUDOMONAS SP. PS 17. 1. ОДЕРЖАННЯ ТА ТЕРМІЧНІ ХАРАКТЕРИСТИКИ}

\begin{abstract}
Анотація. Одержсано нові продукти біосинтезу штаму Pseudomonas sp. PS-17: біогенні поверхнево-активні речовини (рамноліпідний біокомплекс, дирамноліпід та екзополісахарид) i біополімер полігідроксіалканоат. Вивчено прочес термічного перетворення иих продуктів у повітряному середовищі в інтервалі температур 293-1273 К. За результатами термолізу та ІЧ-спектроскопії виявлено утворення рамноліпідного біокомплексу між рамноліпідами та екзополісахаридом при підкисленні супернатанту культуральної рідини до рH=3. Методом UV-Vis спектроскопї (за максимумом поглинання при 239 нм) ідентифіковано клітинний полімер - полігідроксіалканоат. За даними термічного аналізу визначено температуру плавлення полігідроксіалканоату (319 К) та температуру початку його деструкиї (499 K). 3 використанням методу Віка визначено теплостійкість полімеру, щэо склала $321 \mathrm{~K}$.
\end{abstract}

Ключові слова: Pseudomonas sp. PS-17, біоПАР, рамноліпіди, полісахариди, полігідроксіалканоати, біополімери, термічний аналіз, UV-Vis спектроскопія, IЧ спектроскопія. 